\title{
WestVirginiaUniversity
}

THE RESEARCH REPOSITORY @ WVU

West Virginia Agricultural and Forestry Experiment

Davis College of Agriculture, Natural Resources

Station Bulletins

And Design

$1-1-1984$

\section{Lumber drying in West Virginia : results of an industry survey}

James P. Armstrong

Follow this and additional works at: https://researchrepository.wvu.edu/ wv_agricultural_and_forestry_experiment_station_bulletins

\section{Digital Commons Citation}

Armstrong, James P., "Lumber drying in West Virginia : results of an industry survey" (1984). West Virginia Agricultural and Forestry Experiment Station Bulletins. 689.

https://researchrepository.wvu.edu/wv_agricultural_and_forestry_experiment_station_bulletins/583 @ WVU. It has been accepted for inclusion in West Virginia Agricultural and Forestry Experiment Station Bulletins by an authorized administrator of The Research Repository @ WVU. For more information, please contact ian.harmon@mail.wvu.edu. 


\section{$\overline{\text { IUMBER DRYING }}$ WEST VIRGINIA RESULTS OF AN INDUSTRY SURVEY}

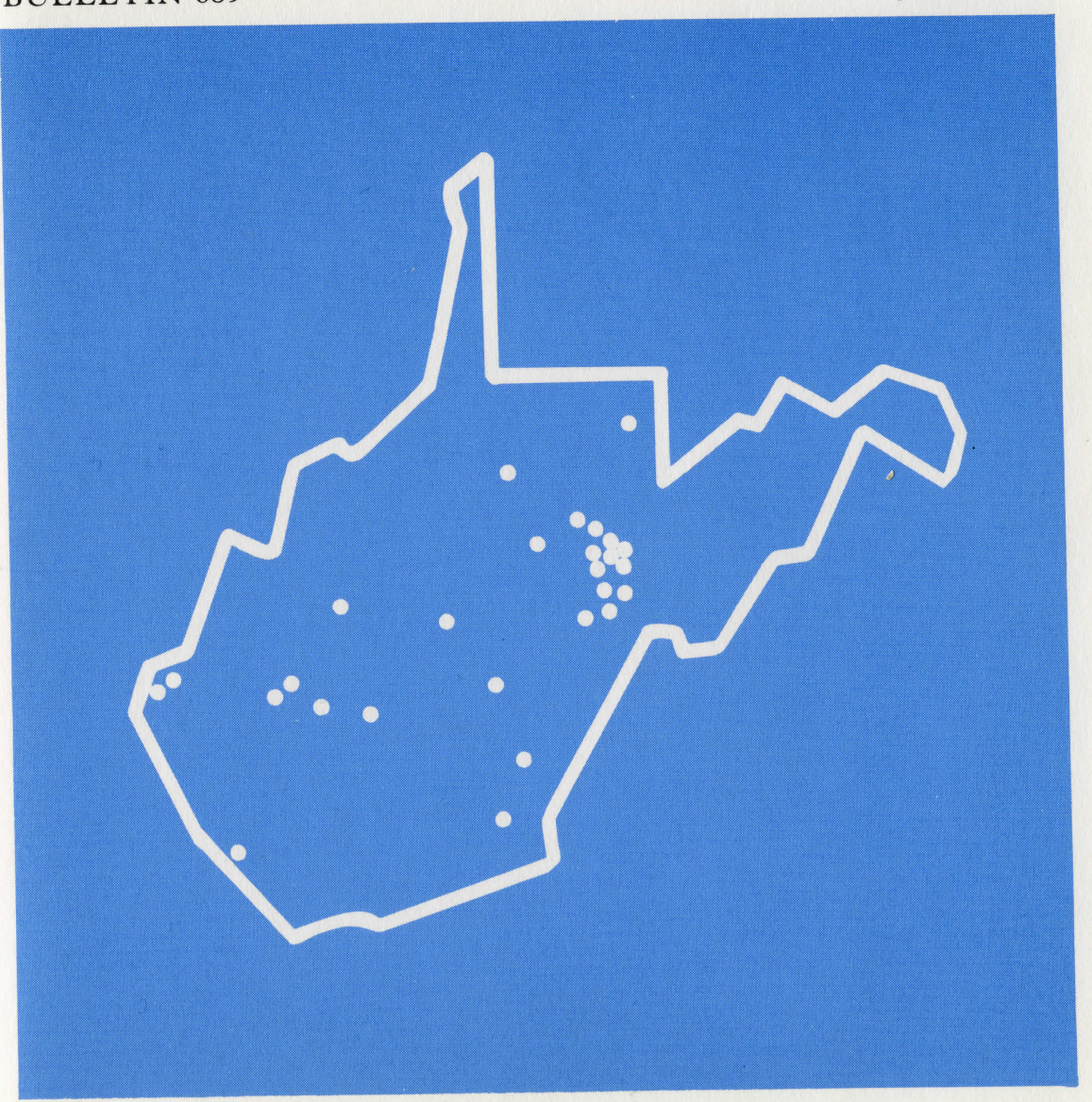




\section{Author}

James P. Armstrong is assistant wood scientist in the Agricultural and Forestry Experiment Station, and assistant professor of wood science in the Division of Forestry, West Virginia University.

West Virginia University Agricultural and Forestry Experiment Station College of Agriculture and Forestry

Dale W. Zinn, Director Morgantown

\section{Contents}

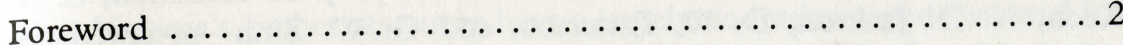

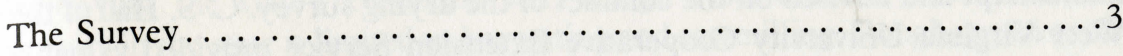

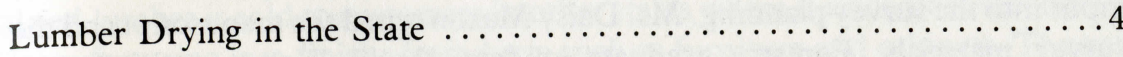

Kiln Equipment in West Virginia $\ldots \ldots \ldots \ldots \ldots \ldots \ldots \ldots \ldots \ldots \ldots \ldots \ldots \ldots \ldots \ldots$

1982 Kiln Drying Production $\ldots \ldots \ldots \ldots \ldots \ldots \ldots \ldots \ldots \ldots \ldots \ldots \ldots \ldots \ldots$

Fuel Used for Kiln Drying $\ldots \ldots \ldots \ldots \ldots \ldots \ldots \ldots \ldots \ldots \ldots \ldots \ldots \ldots \ldots \ldots$

Kiln Drying Practices $\ldots \ldots \ldots \ldots \ldots \ldots \ldots \ldots \ldots \ldots \ldots \ldots \ldots \ldots \ldots \ldots \ldots \ldots \ldots$

Anticipated Growth of Kiln Drying Capabilities $\ldots \ldots \ldots \ldots \ldots \ldots$

Drying Research Priorities for West Virginia $\ldots \ldots \ldots \ldots \ldots \ldots \ldots \ldots$

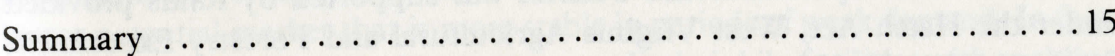

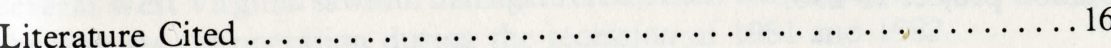

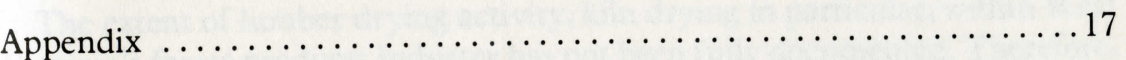




\section{Lumber Drying in West Virginia: Results of an Industry Survey}

\section{Foreword}

The author is grateful to the many individuals who contributed to this project. His colleagues in the Division of Forestry-J. R. Hamilton, C. B. Koch, N. D. Jackson, D. W. Patterson, and G. W. Zinn-reviewed the manuscript and advised on the conduct of the drying survey. C. S. Hall of the West Virginia University Cooperative Extension Service provided valuable input into the survey planning. Ms. Daisy Maxon typed the manuscript and the survey materials. Forestry graduate student David Walton assisted with gathering data on 1982 kiln drying volumes.

Mr. Edward Murriner of the West Virginia Department of Natural Resources was extremely helpful in reviewing the survey document and in suggesting forest products companies to be surveyed. Mr. Richard Waybright of West Virginia Forests, Inc. also suggested mills to be contacted. Murriner and Ms. Karen Price of the Governor's Office of Economic and Community Development also reviewed the manuscript. Of course, the forest products industry managers who contributed so much to our survey are most responsible for the success of this project.

The research reported in this bulletin was supported by funds provided under the Hatch Act, West Virginia Agricultural and Forestry Experiment Station project $\mathrm{H}-296$.

\section{James P. Armstrong}

West Virginia's timber resources have a largely underdeveloped potential for improving the state's economic well-being. Most current forest industry activity in the state is limited to harvesting and sawmilling. Rough, green or air dried lumber is sold to customers in other states where it undergoes secondary manufacturing into finished products such as furniture and cabinets. The net result is that West Virginia realizes relatively little value added to its timber resource by manufacture as compared to neighboring states and national averages (Foster 1981).

The low level of kiln drying activity in the state's forest products industry is an indication of the weakness of West Virginia's secondary manufacturing industry. Conversely, development of small to moderate-sized secondary processing plants is hindered by the lack of local kiln dried lumber suppliers. Kiln drying capability also offers advantages to sawmill operators (Fields and Duncan 1981). Sawmills can realize greater profits by kiln drying their higher grade lumber. Perhaps more importantly, kiln drying offers the advantages of a larger potential market that is more stable in periods of weak demand. In fact, several West Virginia sawmill managers credit their kiln facilities with enabling them to stay in operation during the recession of 1981 and 1982.

The extent of lumber drying activity, kiln drying in particular, within West Virginia's forest products industry has not been fully documented. Therefore, this study was undertaken to identify the state's kiln operators and major lumber air driers, assess their current capabilities and anticipated growth, and analyze specific problem areas and technological needs of the industry. To meet these objectives, a mail survey of the state's forest products industry was conducted by the Division of Forestry of West Virginia University and the West Virginia Agricultural and Forestry Experiment Station.

\section{The Survey}

The survey was conducted using the "Total Design Method" developed by Donald A. Dillman (1978). This method includes an initial mailing and at least three subsequent follow-ups at intervals of one, three, and seven weeks later. A copy of the questionnaire is included in Appendix A. 
Questionnaires were mailed to West Virginia sawmills producing more than one million board feet per year, secondary manufacturers employing 30 or more people, and smaller mills and custom kiln driers or concentration yards identified by one of our sources as a kiln operator. Mill names were obtained from the primary and secondary forest industry directories published by the West Virginia Department of Natural Resources $(1972,1980)$ and from the West Virginia Manufacturing Directory (West Virginia G.O.E.C.D. 1980-81) Several additional mill names were provided by Edward Murriner of the West Virginia DNR and Richard Waybright of West Virginia Forests, Inc.

A total of 142 companies were surveyed on or after April 19, 1983. Six questionnaires were returned (undelivered) by the Postal Service. Of the 136 remaining mills, 123 responded to the questionnaire. The response rate of slightly better than 90 percent is a tribute to the cooperation of West Virginia's forest industry managers and to Dillman's Total Design Method.

\section{Lumber Drying in the State}

Of the mills responding to the survey, 52 (42 percent) air dry or kiln dry lumber Twenty-six mills operate dry kilns and one mill is constructing kilns. A 2,000board foot solar kiln is also being operated commercially in West Virginia.

Drying is a necessary intermediate step between primary conversion of logs into lumber and secondary manufacture of wood products. A number of secondary manufacturers prefer to kiln dry lumber at their mills (Fields and Duncan 1981) so it is of particular interest to identify West Virginia's air drying and kiln drying firms according to their principal activities.

Of the 24 mill operators engaged only in air drying, 23 operate sawmills. Two of the mills operate treating plants, one operates a planer mill, and another produces fencing. Twenty of the 23 sawmills produce over one million board feet of lumber per year and eight of these produce over five million board feet. One million board feet is generally considered to be the approximate minimum production to justify installing a conventional dry kiln (Fields and Duncan 1981). This suggests that these mills would be prime candidates for conducting feasibility studies for installing kilns. In fact, several of these mills are considering this option.

The kiln drying firms represent a greater diversity of operations. Twelve of 27 mills operating or constructing kilns operate sawmills. Sixteen kiln operations are associated with some phase of secondary manufacture (planer mills, treating plants, millwork, furniture dimension and panel manufacturers, and finished furniture, casket, or similar manufacturing). Four concentration yards operate dry kilns. Five West Virginia kiln operations engage in custom kiln drying.

Drying operations are located in 25 counties in West Virginia. Dry kilns are located in 13 counties with the greatest concentration (ten operations) in

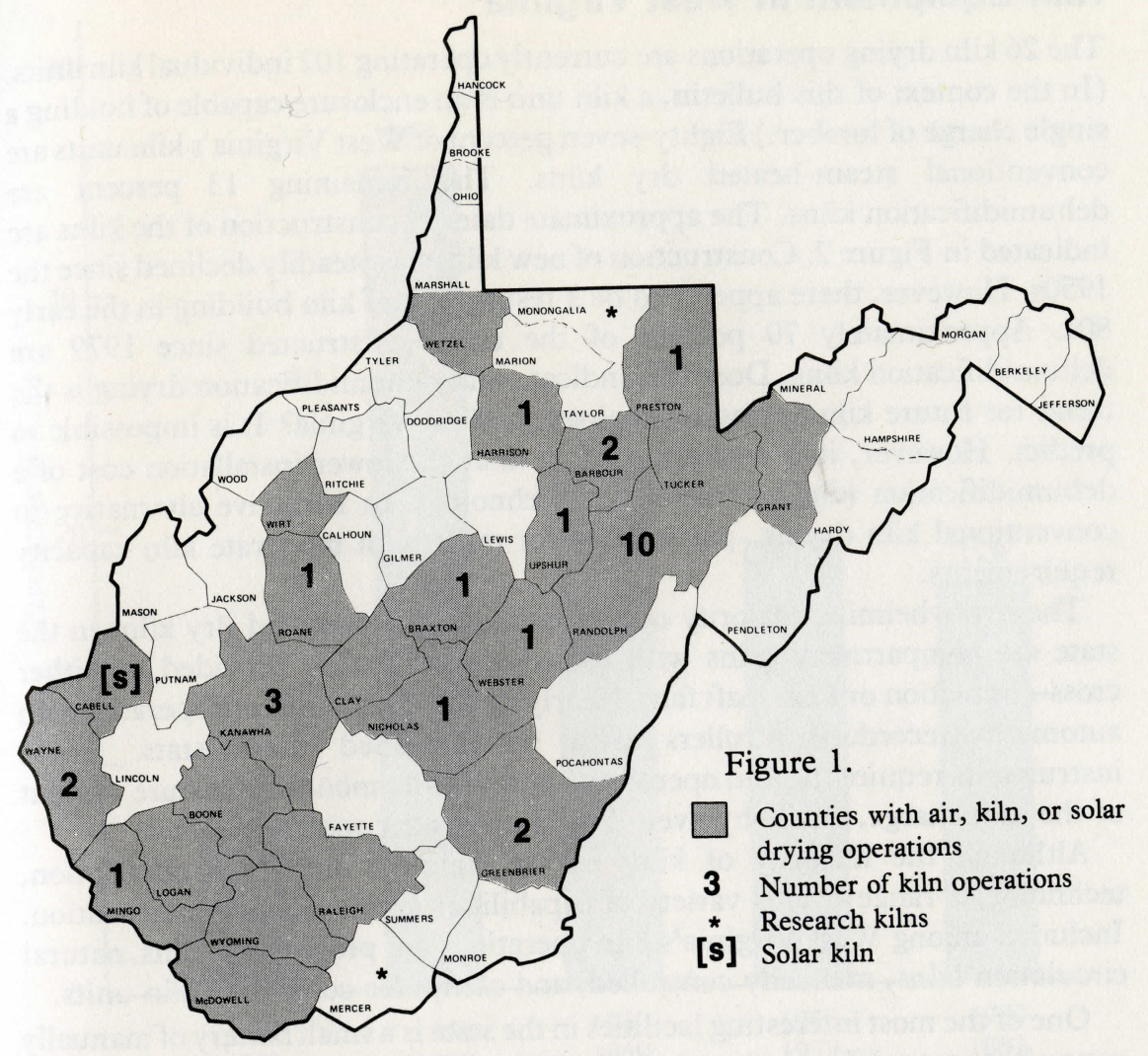

Randolph County. Three kiln operations are located in Kanawha County and two each are located in Barbour, Greenbrier, and Wayne counties. Counties containing kilns and air drying operations are illustrated in Figure 1.

Two research kilns are active in West Virginia. One is operated for the research and educational programs of the Division of Forestry of West Virginia University in Morgantown. The other is operated by the U.S. Forest Service at the Forestry Sciences Laboratory in Princeton. Both are small, conventional steam-heated kilns. The Forestry Sciences Laboratory also operates an experimental forced-air predrier.

There are at least three inactive batteries of kilns in West Virginia. It is believed that one of these was for sale at the time of this writing and may be back in production in the near future. 


\section{Kiln Equipment in West Virginia ${ }^{1}$}

The 26 kiln drying operations are currently operating 102 individual kiln units. (In the context of this bulletin, a kiln unit is an enclosure capable of holding a single charge of lumber.) Eighty-seven percent of West Virginia's kiln units are conventional steam-heated dry kilns. The remaining 13 percent are dehumidification kilns. The approximate dates of construction of the kilns are indicated in Figure 2. Construction of new kilns has steadily declined since the 1950s. However, there appears to be a resurgence of kiln building in the early 80 s. Approximately 70 percent of the units constructed since 1979 are dehumidification kilns. Does this indicate that dehumidification drying is the trend for future kiln drying technology in West Virginia? It is impossible to predict. However, it is entirely possible that the lower installation cost of a dehumidification kiln has made this technology an attractive alternative to conventional kiln drying, particularly for mills with moderate kiln capacity requirements.

The overwhelming majority of conventional steam-heated dry kilns in the state are compartment kilns with forced-air circulation provided by either cross-circulation or line-shaft fans. Nearly all of the kiln units are operated with automatic recorder-controllers with self-contained thermostats. These instruments require the kiln operator to periodically monitor moisture content of the kiln charge, either by oven-drying or electric moisture meter.

Although the majority of kilns in the state fit the above description, technologies range over a variety of capabilities and levels of sophistication. Included among West Virginia's kiln operations are progressive kilns, natural circulation kilns, manually controlled, and computer controlled kiln units.

One of the most interesting facilities in the state is a small battery of manually controlled steam kilns designed and built by the Cutler Flooring Company in 1917. These kilns were originally operated with a cold-air plenum chamber on either side of the kiln which served to condense and remove moisture from the kiln chamber by much the same principle as modern dehumidification dry kilns. The kilns are now used as conventional compartment units for drying yellow-poplar lumber. The current operator believes that his Cutler kilns are unique and he is justifiably proud of making the best use of his existing facilities.

In contrast, another West Virginia mill is operating a large battery of stateof-the-art dehumidification kilns controlled by computer. Moisture content of lumber in the kilns is continuously monitored by electronic moisture meters which read directly into the computer. The operator of these units is capable of controlling his kilns from an office computer terminal. At least one other West

'For a definition of technical terms used in this bulletin, the reader may refer to the Dry Kiln Operator's Manual (Rasmussen 1961).

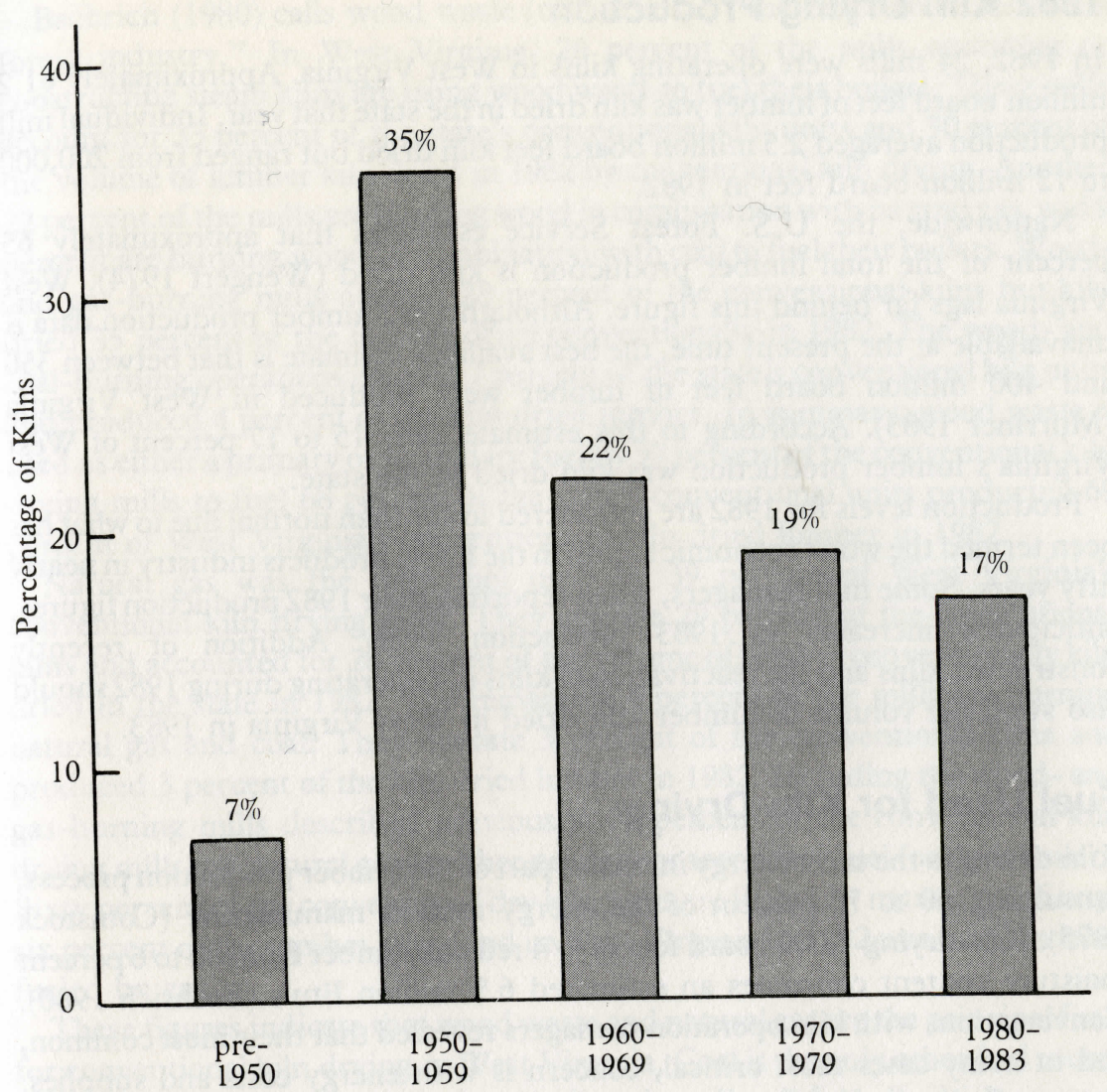

Dates of Construction

Figure 2. Approximate construction dates of active dry kilns in West Virginia.

Virginia firm is experimenting with continuous electronic metering of lumber moisture content in its dry kilns.

Approximately 40 percent of West Virginia's kiln units are concrete block structures. Thirty-six percent (for the most part constructed in the past twenty years) are aluminum clad, steel frame, prefabricated buildings. Another 14 percent, mostly older units, are brick buildings. The remaining 10 percent are wood-frame, pole-construction, or other masonry construction buildings. 


\section{Kiln Drying Production}

In 1982, 24 mills were operating kilns in West Virginia. Approximately 61.2 million board feet of lumber was kiln dried in the state that year. Individual mill production averaged 2.5 million board feet kiln dried but ranged from 200,000 to 12 million board feet in 1982

Nationwide, the U.S. Forest Service estimates that approximately 65 percent of the total lumber production is kiln dried (Wengert 1974). West Virginia lags far behind this figure. Although 1982 lumber production data is unavailable at the present time, the best available estimate is that between 350 and 400 million board feet of lumber were produced in West Virginia (Murriner 1983). According to this estimate, only 15 to 17 percent of West Virginia's lumber production was kiln dried in the state.

Production levels for 1982 are considered lower than normal due to what has been termed the worst economic slump in the forest products industry in nearly fifty years. Some mill managers, when reporting their 1982 production figures, anticipated increases in 1983 production levels. Addition of recently constructed kilns and the reactivation of kilns not operating during 1982 should also swell the volume of lumber kiln dried in West Virginia in 1983.

\section{Fuel Used for Kiln Drying}

Kiln drying is the most energy intensive part of the lumber production process, consuming 60 to 70 percent of the energy used in manufacture (Comstock 1975). Kiln drying 1,000 board feet of $4 / 4$ red oak lumber from 80 to 6 percent moisture content consumes an estimated 6.5 million Btu's (Bachrich 1980). Conversations with kiln operation managers revealed that their most common, and in many cases most critical, concern is with energy costs and supplies. Current fuel usage for West Virginia's conventional kilns is shown in Table 1.

Table 1.

Fuel usage of West Virginia's 23 conventional steam kiln operators

\begin{tabular}{lccc}
\hline Fuel & $\begin{array}{c}\text { Percentages } \\
\text { of } \\
\text { Mills }\end{array}$ & $\begin{array}{c}\text { Percentages } \\
\text { of } \\
\text { Kilns }\end{array}$ & $\begin{array}{c}\text { Percentages } \\
\text { of } 1982 \\
\text { Production }\end{array}$ \\
\hline Wood (mill residue) & 26 & 33 & 30 \\
Natural gas & 39 & 29 & 28 \\
Wood \& gas & 22 & 28 & 35 \\
Wood \& coal & 9 & 7 & 4 \\
Gas \& coal & 4 & 3 & 3 \\
\hline
\end{tabular}
*Includes production from only 22 mills. One natural gas-burning operator was not kiln drying in
1982 .
Bachrich (1980) calls wood waste (mill residue) "the traditional fuel of the forest industry." In West Virginia, 26 percent of the mills operating or constructing steam kilns are using wood waste to fuel their boilers. These mills account for 33 percent of the state's conventional kiln units and 30 percent of the volume of lumber kiln dried in 1982 by conventional kiln drying. Another 22 percent of the mills are burning wood in combination with natural gas, and 9 percent are burning wood in combination with coal to fuel their boilers. Woodand gas-burning mills operate 28 percent of the conventional kilns but kiln dried 35 percent of the lumber dried conventionally in 1982. The wood-and coal-burning operations contain 7 percent of the state's conventional kiln units and produced 4 percent of the kiln dried lumber. In summary, wood waste is used as either a primary or secondary fuel by 57 percent of the conventional kiln drying mills to fuel 68 percent of the state's conventional units producing 69 percent of West Virginia's conventionally kiln dried lumber in 1982.

Natural gas was the only fuel used by 39 percent of West Virginia's conventional kiln drying mills. They operate 29 percent of the conventional kilns and accounted for 28 percent of the volume of lumber conventionally kiln dried in the state in 1982 . The remaining 4 percent of the mills are burning natural gas and coal. They operate 3 percent of the conventional kilns and produced 3 percent of the kiln dried lumber in 1982. Including the wood-and gas-burning mills described previously, 65 percent of the conventional kiln drying mills use natural gas as either primary or secondary fuel for their boilers Sixty percent of the conventional dry kiln units are fueled by natural gas. Sixtysix percent of the lumber kiln dried in West Virginia in 1982 was dried in kilns fueled by gas.

These figures indicate that wood waste and natural gas are the principal fuels for conventional kiln drying in West Virginia. Coal is the only other fuel source of note. Several mills have back-up boilers (usually oil fueled) which are used only in emergency situations. These boilers are not included in the statistics quoted above. Dehumidification kilns are also not included in these figures since they require electricity as a power source. Most dehumidification kilns now include an auxiliary steam supply in order to condition lumber to alleviate the stresses that cause casehardening. Fuels used to operate the steam supply in these kilns are likewise not included in the statistics. Only 23 percent of the dehumidification kilns operating in West Virginia in 1983 were operating in 1982. Therefore, their contribution to the volume of lumber kiln dried in the state in 1982 was relatively insignificant (less than 1 percent).

\section{Kiln Drying Practices}

Kiln operators have long realized the value of partially drying lumber prior to kiln drying to a final desired moisture content. The practice of predrying enables kiln operators to save energy costs and reduce kiln residence time for a 
charge of lumber. This is especially advantageous in drying slow-drying hardwoods and is common practice in West Virginia. Twenty-three percent of the state's kiln operators always predry, either by air drying or in a forced-air predrier. Twenty-seven percent usually predry or express a preference for predrying prior to kiln drying. In comparison, 8 percent always and 11 percent usually kiln dry green lumber with no predrying. The remaining 31 percent express no preference or make the decision whether or not to predry depending upon circumstances of orders, production, and inventory

Two of West Virginia's kiln driers also operate forced-air predriers.

Relief of internal stresses that cause casehardening is an important step in drying hardwood lumber for remanufacture into secondary products. Sixtynine percent of the state's kiln operators always include a conditioning or stressrelief step in their drying schedule. Another 19 percent sometimes employ this practice. Twelve percent never condition their lumber, probably due to limitations imposed by their kiln equipment.

Red oaks are the major commercial timber species grown in West Virginia They account for approximately 31 percent of the state's sawlog production (Bones and Glover 1977) and are listed by 85 percent of the state's kiln driers as their most frequently dried species. White oaks and yellow-poplar are also frequently kiln dried by most West Virginia mills. This is not surprising since these two species each account for 16 percent of the state's sawlog production (Bones and Glover 1977). Basswood, black cherry, hard maple, soft maple, and walnut are also commonly kiln dried at West Virginia mills. A few kiln operators in the state also dry quantities of ash, butternut, beech, birch, hickory, sycamore, mahogany, redwood, and spruce.

\section{Anticipated Growth of Kiln Drying Capabilities}

Mill managers were asked if they planned to install or improve drying facilities within the next five years. Thirty responded affirmatively. Of this number, ten mills that do not have dry kilns are considering installing kilns. Four current kiln operations are planning to install additional kilns and eight are planning improvements of existing kilns.

Eight respondents to the survey are considering installing predriers (it is assumed they will be forced-air predriers) and four plan to build air drying sheds. Two mill managers expressed interest in vacuum (high-temperature vacuum?) drying as a potential alternative to traditional kiln drying methods.

These responses reflect an optimistic attitude of anticipated growth in West Virginia's forest products industry. However, the survey question about anticipated growth was necessarily vague as were some of the responses. Thus, readers are cautioned that the "plans" cited above may range from mill management "thinking about" improvements to mills where the improvements are already under construction at the time of this publication. As with all plans for industrial expansion, these are closely tied to the state of the conomy, particularly interest rates and taxation. It is encouraging to note, 列 however, the construction of new kilns that has taken place in the state over the past few years and the prospect of future growth indicated by the above responses. The apparent recovery from the recession of 1981-82 and the increase in lumber production expected in 1983 should stimulate growth of kiln drying capabilities within the state.

\section{Drying Research Priorities for West Virginia}

Scientists spend much time evaluating areas where research is needed and stablishing priorities for specific topics for investigation. In one section of the establishing prioril managers were asked for their opinions on topics of current research interest in lumber drying. It is hoped that their responses will be helpful to inter of reserch and technology scientists (and meaningful to the state's forest products industry.

transfer that are meaningful to the state's 14 topics as either "not a priority," a "low

Respondents were asked to rate 14 topics as either "not a priority," a "low priority," a "medium priority," or a "high priority." Nine of the topics were borrowed from a recent survey of eastern hardwood lumber and dimension manufacturers conducted by the Hardwood Research Council (McLintock 1979). This was done so that results of this survey of West Virginia's industry could be compared to McLintock's broader survey of Whe order to focus on the more localized needs study of the Eastern Unich research areas were: (1) predrying, (2) air drying, (3) of the state. McLintock's research areas were: (1) predrying, (2) air drying, (3) high temperature drying, (4) better kiln drying (automation, quality control, etc.), (5) solar drying, (6) dehumidification drying, (7) stain prevention, (8) drying short lumber, and (9) better cost/benefit information. To this list the survey used in this study added: (10) the Saw-Dry-Rip (S-D-R) method, (11) radio-frequency vacuum drying, (12) improved wood-fueled boiler systems, (13) stickering, stacking, and warp control, and (14) storage of dry lumber.

Re the topics they believed were of Respondents were also asked to rate the ther to generate a useful ranking of greatest potential benefit to their firm. In order to generate a useful ranking of priorities for the 14 topics, a relatively arbitrary point scale was assigned to the survey responses. For each topic, a value of one, four, seven, or ten points was assigned for each response marked "not a priority," "low priority," "medium priority," or "high priority," respectively. To the total, three points were added for each response listing the topic to be "most important" to the respondent's for each response listing the topic to be "mosts for each response marked "second most important," and one point for each response marked "third most important." The number of points for each topic was then averaged by the number of responses. This made it possible to establish a relative ranking of priorities among the topics. Results were separated into responses from kiln operators and air driers (both summarized in Table 2) 
Table 2.

Summary of research priority results

\begin{tabular}{|c|c|c|c|c|}
\hline \multirow[b]{2}{*}{ Topic } & \multicolumn{2}{|c|}{$\begin{array}{c}\text { Kiln Operators } \\
\text { (22 responses) }\end{array}$} & \multicolumn{2}{|c|}{$\begin{array}{c}\text { Air Driers } \\
\text { (23 responses) }\end{array}$} \\
\hline & rating & rank & rating & rank \\
\hline 1. Predrying & 9.14 & 4 & 8.45 & 4 \\
\hline 2. Air Drying & 7.73 & 7 & 7.86 & 7 \\
\hline 3. High Temperature Drying & 6.90 & 9 & 6.22 & 12 \\
\hline \multicolumn{5}{|l|}{$\begin{array}{l}\text { 4. Better Kiln Drying } \\
\text { (automation, quality }\end{array}$} \\
\hline control, etc.) & 9.63 & 3 & 7.37 & 8 \\
\hline 5. Solar Drying & 5.65 & 12 & 6.58 & 11 \\
\hline 6. Dehumidification Drying & 6.47 & 10 & 7.21 & 9 \\
\hline 7. Stain Prevention & 8.75 & 6 & 8.13 & 5 \\
\hline 8. Drying Short Lumber & 4.67 & 14 & 4.67 & 14 \\
\hline \multicolumn{5}{|l|}{ 9. Better Cost/Benefit } \\
\hline Information & 8.79 & 5 & 8.75 & 3 \\
\hline 10. Saw-Dry-Rip & 4.94 & 13 & 4.90 & 13 \\
\hline 11. R-F Vacuum Drying & 6.05 & 11 & 6.75 & 10 \\
\hline 12. Improved Wood-Fueled & & & & \\
\hline Boiler Systems & 10.65 & 1 & 8.95 & 2 \\
\hline \multicolumn{5}{|l|}{ 13. Stickering, } \\
\hline Stacking, and Warp & & & & \\
\hline Control & 9.67 & 2 & 9.13 & 1 \\
\hline 14. Storage of Dry Lumber & 7.43 & 8 & 7.95 & 6 \\
\hline
\end{tabular}

The primary concerns of West Virginia's kiln managers are energy costs and the use of wood waste (mill residue) for fuel. The survey results show improved wood-fueled boiler systems to be the highest rated priority for research. Conversations with mill managers emphasized this point. Several kiln operators said that rising fossil fuel costs were forcing them to either convert to wood-fueled boilers or go out of business. Many of the natural gas burning kilns are not operated at temperatures higher than $160^{\circ} \mathrm{F}$ in order to reduce fuel costs to what the operators consider reasonable levels. Mill managers who operate wood-fueled boilers sometimes face difficulty with mill residue shortages, therefore available supplies of residue also need to be identified. It is apparent that better information concerning available wood-fueled boiler technology and the economic feasibility of producing steam for dry kilns by burning mill residue must reach kiln managers and potential kiln managers in the state.
McLintock's (1979) survey of eastern hardwood lumber and dimension manufacturers, and furniture manufacturers also identifies energy-related questions as the top research priorities among over fifty possible topics dealing with all phases of lumber and furniture production.

The general subject area of better cost/benefit information also received high priority ratings, ranking third in importance among air driers and fifth among kiln operators. Does the high ranking by air driers reflect that some of them may be considering the potential benefits of installing kilns or predriers? may be considering the potential benefits of installing kilns or predriers? Perhaps, but not absolutely certain from these results. This topic was also considered important in the McLintock (1979) survey. Although the question in this survey (and McLintock's) did not identify specific items for which in this survey (and McLintock's) did not identify specific items for which cost/benefit information is most needed, it can be assumed that this would correlate closely with those items also given high priority rankings. For example, better cost/benefit information on wood-fueled boilers is a high priority topic.

Predrying is also a high priority item, ranking fourth according to both air driers and kiln operators. Eighty percent of the state's kiln operators currently predry by air drying or forced-air predrier and, as stated previously, several mills are considering installing forced-air predriers. McLintock (1979) observed that predrying was important to furniture manufacturers but of substantially lower priority to lumber and dimension manufacturers.

Kiln operators rated better kiln drying as the third highest priority. This Kiln operators rated beth air driers. McLintock's (1979) furniture topic was important in lumber drying. His lumber and dimension manufacturers considered it second most important among his nine lumber drying topics. Earlier the developing trend in Wes Virginia toward automation was discussed, specifically in continuous electronic monitoring of moisture content and computer control of the drying process. monitoring of moisture for technological development by the private sector. It is expected that resulting improvements will be gradually adopted by West Virginia's industry, particularly in newer kilns.

Stain prevention was not considered very important by the industry managers surveyed by McLintock (1979). However, West Virginia managers consider the search for effective but safe methods to control fungi to be a relatively high priority topic for research. The response of the West Virginia mill means of drying lumber or as the dominant method for predrying. Since air d drying is a relatively slow process, conditions for fungal attack are magnified as compared to kiln drying or forced-air predrying. One of the mill managers in the survey provided further insight on the problem by commenting that strict EPA regulation has limited the use of some of the used to spray or dip lumber for stain control. 
The general research topic of air drying was given a moderately important rating by survey respondents as was storage of dry lumber. Technology of both topics has been rather thoroughly researched so it is believed that survey responses may indicate a need for improved industrial practices or improved technology transfer.

Stickering, stacking and warp control is also an area in which current research interest is limited. Yet, this topic was considered of principal importance to air driers and ranked second to wood-fueled boiler systems in the opinion of the kiln driers. The high ratings given this subject clearly indicate the concern of industry management over current practice. Perhaps scientists need to revaluate traditional stacking and warp control procedures in an effort to devise a better method. The response may also result in part from poor industrial practice.

Ironically, topics that are generating a great deal of interest in the scientific and academic community are considered as low priorities by mill managers. High temperature drying, dehumidification drying, radio-frequency vacuum drying (Tubby 1983), solar drying, the U.S. Forest Products Laboratory's Saw-Dry-Rip method (Maeglin 1978), and methods for drying short lumber or dimension parts (Simpson and Schroeder 1980) are given the lowest priority ranking by survey respondents. Most surprising was the low ranking given to dehumidification drying. It has been proven to be technologically viable as evidenced by the four West Virginia mills that have adopted the technology. McLintock's (1979) survey of eastern hardwood lumber and dimension manufacturers listed dehumidification drying as highest priority among drying research topics. McLintock's lumber industry respondents also rated sola drying as a higher priority objective than our respondents. Conversely, they give air drying and predrying lower ratings than did West Virginia mill managers.

Responses in this survey indicate a need for improved communication between industry and people engaged in wood products research in West Virginia. It is important for the state's industry to have input in research planning in lumber drying. Several issues raised in this discussion, such as the importance placed upon warp control by the mill managers, indicate that there is a need for industry to make its technological needs known.

It is also apparent that many of the issues mislabeled as "research" priorities actually point to a need for improved technology transfer. Specific comments of survey respondents tend to support this conclusion. Several mill managers expressed a desire for improved technology transfer activities in West Virginia. Included in their suggestions were lumber drying workshops, formation of a kiln drying association in the state, and expanded field activity by the West Virginia Cooperative Extension Service. The questionnaire specifically addressed the question of drying workshops. Only six of 123 respondents indicated that one or more of their employees had attended a lumber drying workshop (in another state) within the past five years. However, 43 mill managers expressed interest in sending an employee if a shortcourse were offered at a convenient time and location. These comments and the responses to research priority questions indicate improved technology transfer efforts have a very high priority in West Virginia.

\section{Summary}

The survey of West Virginia mills revealed that lumber drying activity is currently at a relatively low level. Only 27 of the state's mills are operating or constructing dry kilns, and, in 1982, an estimated 15 to 17 percent of West Virginia's lumber production was kiln dried in the state. However, recent expansion of kiln drying facilities and an optimistic attitude on the part of mill managers is an indication of potential growth of drying capabilities in the state in the immediate future.

Existing drying technologies in the state vary, but most facilities contain conventional steam-heated compartment kilns equipped with automatic recorder-controller instruments. The trend is currently toward a higher percentage of dehumidification kilns and more sophisticated automation. There is also a trend toward replacing natural gas-fired boilers with wood waste fuel systems.

West Virginia mill managers seem most interested in research on topics relating to drying practices that they are currently using. They appear less interested in long-term subjects such as new drying methods and utilization of low value hardwoods. There is a critical need in the state for expanded technology transfer activities and for better industrial input into drying research programs. The importance of active research and technology transfer programs in West Virginia was best expressed by one of the state's mill managers who commented on his survey questionnaire: "This company . . (has) been kiln drying lumber for many years and we still do not know much about kiln drying lumber and do not know of anybody else that does." 


\section{Literature Cited}

Bachrich, J. L. 1980. Dry Kiln Handbook. H. A. Simons (International) LTD. Vancouver, B. C., Canada.

Bones, J. T. and R. P. Glover, Jr. 1977. The timber industries of West Virginia. USDA Forest Service. Northeastern Forest Experiment Station, Resource Bulletin NE-47. Broomall, $\mathrm{Pa}$.

Comstock, G. L. 1975. "Energy requirements for drying of wood products." Proc. No. P-75-13. Wood Residues as an Energy Source: 8-12. Denver, Colo., September 3-5, 1975. Published by Forest Products Research Society, Madison, Wis.

Dillman, D. A. 1978. Mail and Telephone Surveys: The Total Design Method. John Wiley and Sons. New York, N.Y.

Fields, T. D. and W. A. Duncan. 1981. Kiln drying hardwoods in East Kentucky: A feasibility and design analysis. Mountain Assoc. for Community Economic Development (MACED). September 1981, Berea, Ky.

Foster, B. B. 1981. "Some interesting comparisons among states," Southern Lumberman 242(3016): 93-96.

Maeglin, R. R. 1978. "Yellow-poplar studs by S-D-R," Southern Lumberman 237(2944): 58-60

McLintock, T. F. 1979. Research priorities for Eastern hardwoods. Hardwood Research Council. May 1979, Asheville, N.C.

Murriner, E. 1983. Personal communication. West Virginia Department of Natural Resources. Division of Forestry. Charleston, W.Va.

Rasmussen, E. F. 1961. Dry Kiln Operator's Manual. USDA Agr. Handbook No. 188. Washington, D.C.

Simpson, W. T. and J. G. Schroeder. 1980. "Kiln-drying hardwood dimension parts." USDA Forest Service. Forest Products Laboratory, Research Paper FPL-388. Madison, Wis.

Tubby, G. B. 1983. "R-F drying advances lumber drying technology," Forest Industries 110(6): 30-31.

Wengert, E. M. 1974. "How to reduce energy consumption in kiln drying lumber." USDA Forest Service. Forest Products Laboratory, Research Note FPL-0228. Madison, Wis.

West Virginia DNR. 1972. "The secondary forest industry of West Virginia 1972." Department of Natural Resources. Division of Forestry. Charleston, W.Va.

West Virginia DNR. 1980. "The primary forest industry of West Virginia 1980." Department of Natural Resources. Division of Forestry. Charleston, W.Va.

West Virginia G.O.E.C.D. 1980-81. West Virginia 1980-81. Manufacturing Directory. Governor's Office of Economic and Community Development. Economic Development Division. Charleston, W.Va.

\section{APPENDIX}

\section{Lumber Drying Practices}

\section{in West Virginia}

An Industry Survey

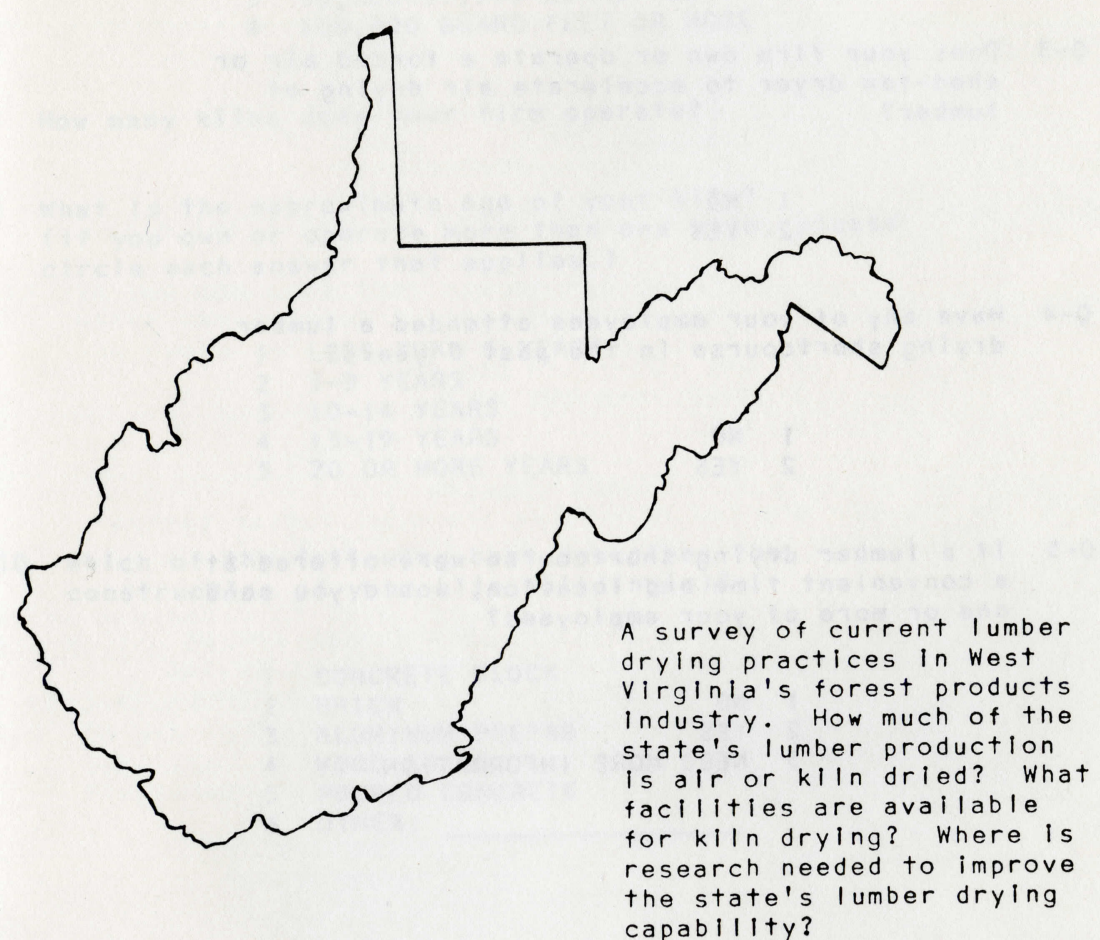

Division of Forestry 206-E Perclval Hall West Virglnia University Morgantown, West Virginia 26506

Please answer all of the questions. If you wish to comment on any question or quallfy your answer, please use the margins or a separate sheet of paper.

Thank you for your help. 
Q-1 Does your firm air dry or kiln dry lumber? (Please clrcle one.)

$\begin{array}{ll}1 & \text { NO } \\ 2 & \text { YES }\end{array}$ IF YOUR FIRM DOES NOT DRY LUMBER PLEASE $0-23$ FROM HERE TO$$
\text { (If yes) }
$$

Q-2 How much of the lumber that you buy, sell, produce, or use is dried at your plant site?

1 LESS THAN ONE FOURTH

ONE FOURTH TO ONE HALF

MORE THAN ONE HALF

Q-3 Does your firm own or operate a forced alr or shed-fan dryer to accelerate alr drying of lumber?

$$
\begin{array}{ll}
1 & \text { NO } \\
2 & \text { YES }
\end{array}
$$

Q-4 Have any of your employees attended a lumber drying shortcourse in the past 5 years?

$$
\begin{array}{ll}
1 & \text { NO } \\
2 & \text { YES }
\end{array}
$$

Q-5 If a lumber drying shortcourse were offered at a convenient time and location, would you send one or more of your employees?

1 NO

3 NEED MORE INFORMATION
Now we would like to ask some questions about klin drying.

Q-6 Does your firm own or operate a dry klln?

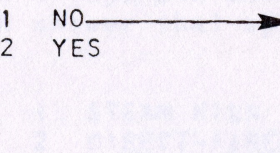

IF YOUR FIRM DOES NOT
OWN OR OPERATE A KILN OWN OR OPERATE A KI $0-20$

(If yes)

Q-7 What is the approximate total capacity of your $k \operatorname{lln}(s)$ per charge?

$$
\begin{array}{ll}
1 & \text { LESS THAN } 25,000 \text { BOARD FEET } \\
2 & 25,000-49,999 \\
3 & 50,000-99,999 \\
3 & \text { BOARD FEET FEET } \\
4 & 100,000 \text { BOARD FEET OR MORE }
\end{array}
$$

Q-8 How many kilns does your firm operate?

Q-9 What is the approximate age of your kiln? ( If you own or operate more than one kiln, please circle each answer that applles.

$$
\begin{array}{ll}
1 & \text { LESS THAN } 5 \text { YEARS } \\
2 & 5-9 \text { YEARS } \\
3 & 10-14 \text { YEARS } \\
4 & 15-19 \text { YEARS } \\
5 & 20 \text { OR MORE YEARS }
\end{array}
$$

Q-10 Which of the following best describes the construction of your kiln building (s)?
CONCRETE BLOCK
BRICK
ALUMINUM PREFAB
WOOD FRAME
POURED CONCRETE
OTHER : 
Q-11 What species does your firm klln dry? (CIrcle any that apply.)

$\begin{array}{ll} & \text { BASSWOOD } \\ 2 & \text { BLACK CHERRY } \\ 3 & \text { HICKORY } \\ 4 & \text { HARD MAPLE } \\ 5 & \text { SOFT MAPLE } \\ 6 & \text { RED OAKS } \\ 7 & \text { WHITE OAKS } \\ 8 & \text { YELLOW - POPLAR/CUCUMBER } \\ 9 & \text { OTHER: }\end{array}$

Q-12 Which species do you kiln dry the most of? (Put number in the approprlate box.)

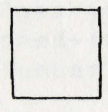
DRY
MOST

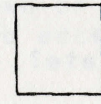
DRY
SECOND SECOND
MOST

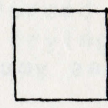

\section{DRY} THIRD

Q-13 What portion of the lumber dried at your plant site do you kiln dry?
1 LESS THAN ONE FOURTH
2 ONE FOURTH TO ONE HAL
4 ALL

Q-14 Do you air dry (or otherwise pre-dry) lumber before kiln drying or do you kiln dry green lumber? 1 ALWAYS AIR DRY BEFORE KILN DRYING NO PREFERENCE (DEPENDS UPON CIRCUMSTANCES) USUALLY KILN DRY GREEN LUMBER

5 ALWAYS KILN DRY GREEN LUMBER

Q-15 Do you include a conditioning or stress-rellef step at the end of your klln-drying schedule?

1 NEVER

SOMETIMES

ALWAYS
Next, would you please answer some questions about the energy requirements of your $k \operatorname{lln}(s)$ ?

Q-16 Which of the following best describes your klin? (If you own or operate more than one kiln, please circle each answer that applies.)

\section{STEAM KILN \\ 2 DIRECT-FIRED KILN \\ 3 ELECTRIC KILN \\ DEHUMIDIFICATION KILN \\ 5 SOLAR KILN}

Q-17 What fuels do you use to heat your dry kiln? (circle that applies).
1 FUEL OIL
2 NATURAL GAS REIDUE)
COAL
ELECTRICITY
6 OTHER:

Q-18 If you use more than one of the above fuels, which one is your primary heat source?

the number of the fuel in the box.)

PRIMARY FUEL

One of the goals of this research is to publish a list of kiln drying operations in the state.

Q-19 Do you object to having your firm listed in a published directory of kiln drying firms in West Virginia?

$\begin{array}{ll}1 & \text { NO } \\ 2 & \text { YES } \\ 3 & \text { NEED }\end{array}$

3 NEED MORE INFORMATION TO DECIDE 
Q-20 Scientists and research administrators spend a great deal of time discussing how they should direct their efforts toward improving umber drying technology. We would like to find out what industry managers believe are the most important areas for lumber drying research. Do you think that each of the following areas is NOT important, or should be a LOW priority area, a MEDIUM priority area, or a $\mathrm{HIGH}$ priority area?

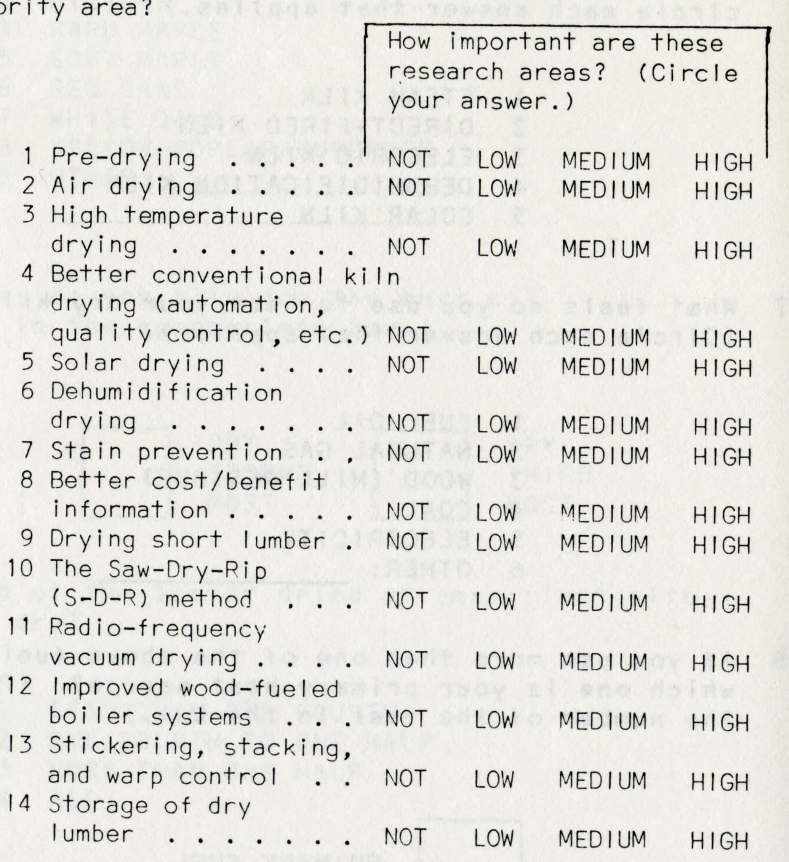

Q-21 Of the areas listed above, which do you believe has greatest potential to benefit your firm? (Put number in the appropriate box.)

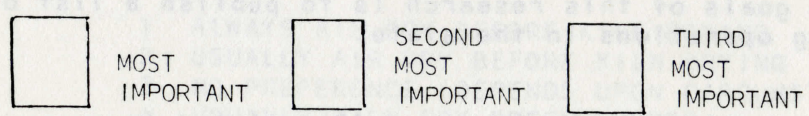

Q-22 What other areas do you think should be given high priority in lumber drying research?
Finally, we would llke to ask a few questions about your fl rm for statistical purposes.

Q-23 What are the princlpal activities of your firm? (Circle any that apply.

\section{SAWMILL \\ FURNITURE PANEL MILL \\ FINISHED FURNITURE OR CABINETS \\ 5. CUSTOM KILN DRYING \\ 6. OTHER:}

Q-24 How much lumber does your firm buy, sell, produce, or use annually?

1. LESS THAN ONE MILLION BOARD FEET

2. I MILLION TO 2 MILLION BOARD FEET

. 2 MILLLION TO 5 MILLION BOARD FEET

4. MORE THAN 5 MILLION BOARD FEET

Q-25 What are your firm's princlpal products?

firm have any plans to install or Improve Does your firm have any plans to instaling yard. drylng facllitles (kilns, sheds.

$$
\begin{array}{ll}
1 & \text { NO } \\
2 & \text { YES }
\end{array}
$$

$(1+$ yes $)$

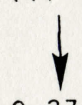

Would you please comment on what improvements are planned? 
Is there anything else you would like to tell us concerning your drying practices? If so, please use this space for that purpose.

Also, any comments you wish to make that you think may help us in developing a research program in lumber drying will be appreclated, elther here or In a separate letter.

Your contribution to this effort is very greatly appreciated. If you would like a copy of our results, please print your name and address on the back of the return envelope (not this questionnairel and we will see that you get it. 